\title{
Geological conditions and gas-bearing evaluation of the Niutitang Formation shale in the Xixiang-Zhenba area, China
}

\author{
Qing $X i e^{1 *, 2}$, Feng $X u^{1 * *, 2}$, Ning Wang ${ }^{1 * * *, 2}$ and Zhen Yang ${ }^{3}$ \\ ${ }^{1}$ Shaanxi Mineral Resources and Geological Survey, Xi'an 710068, P.R.China; \\ (*e-mail corresponding author: xieqingsunny@163.com; **e-mail: Xufeng2@163.com; ***e-mail: 441090192@qq.com) \\ 2 Shaanxi Institute of Geological Survey, Xi'an 710054, P.R.China; \\ ${ }^{3}$ Ministry of Natural Resource, The First Institute of Photogrammetry and Remote Sensing, MNR Xi'an 710054, P.R.China; (e-mail: yangzhen6@qq.com) \\ doi: $10.4154 / g c .2020 .05$

Article history:

Manuscript received April 23, 2019

Revised manuscript accepted February 06, 2020

Available online February 29, 2020

\begin{abstract}
Black carbonaceous shale of the Niutitang Formation in the Xixiang-Zhenba area was found to be well developed and abundant in high-quality shale gas. However, few studies have been conducted in this area, and its reservoir-forming conditions are not clear. This study aims to analyse source rocks, reservoir characteristics and storage conditions of the Niutitang Formation shale in the Xixiang-Zhenba area using field investigations, drilling and logging, supplemented with laboratory experiments. Results of this study shows that the Niutitang Formation shale is deeply buried at $1500-4500 \mathrm{~m}$ and is mainly $10-110 \mathrm{~m}$ thick. The shale is widely distributed, thicker in the west, thinner in the east and is a highly mature organic rich source rock with kerogen type I and II. The shale stratum features a high content of brittle minerals, many natural cracks, and a low content of clay minerals which are mainly illite, followed by a mixed layer of illite and smectite. The shale reservoir is characterized by low porosity and permeability. In addition, the lithology is dense and acts as a good seal in this area while it has a high adsorption capacity and high gas-bearing potential. Overall, within the study area, the western, central, and southern parts have good structural preservation conditions. The Niutitang Formation in the study area shows excellent organic matter characteristics for shale gas generation as well as good geological conditions for shale gas accumulation.
\end{abstract}

Keywords: shale gas reservoir, accumulation conditions, Niutitang Formation, Xixiang-Zhenba area, China
2007; WANG et al., 2015). The Lower Cambrian shale is one source rock of the Sichuan Basin and its surrounding areas. This shale layer is characterized by its large thickness, wide distribution, high level of maturity, and a great potential for gas generation (LI et al., 2009; WU et al., 2014). The Cambrian Niutitang Formation in the Upper Yangtze area of South China has a high organic matter content and high maturity, which lays a material foundation for formation of shale gas reservoirs (HU et al, 2014). Previous studies on the Sichuan Basin have yielded various results regarding the shale distribution and hydrocarbon-generating potential of the organic matter. According to the results, it is believed that the Lower Palaeozoic marine shale satisfies the geological conditions for shale gas accumulation in the Sichuan Basin and its surrounding areas, although it was previously thought to be inferior to the Paleozoic marine shale in the United States (Table 1; RACH, 2004; JARVIE, 2007; WARLICK, 2006; BERMAN, 2009; LI et al., 2013; WANG et al., 2015).

Many studies have been conducted on the Niutitang Formation shale in the Sichuan Basin (ZHOU et al., 1999; MAO et al., 2006; PU et al., 2010; WU et al., 2014; SHEN et al., 2017). Howdeep-water shelf facies and transgressive systems tract MISHE \& KLEMME, 1990; LOUCKS \& RUPPEL, STEPHEN,

Table 1. Comparison of main geological features of gas-bearing shale between the shale gas basin in the United States and the Sichuan Basin in China.

\begin{tabular}{|c|c|c|c|c|c|c|c|}
\hline Basin & Name of the shale & Thickness (m) & Total organic carbon (\%) & Buried depth (m) & Organic matter type & Vitrinite reflectance (\%) & Tectonic movement \\
\hline Fort Worth & Barnett & $61-91$ & $1.00-4.50$ & $1981-2591$ & ॥ & $1.10-1.40$ & Simple \\
\hline Michigan & Antrim & 48.80 & $0.20-20.00$ & $183-671$ & I & $0.40-1.60$ & Simple \\
\hline \multirow{2}{*}{ Sichuan Basin } & Longmaxi Formation & $30-120$ & $1.88-4.36$ & $1600-8000$ & 1 & $2.60-3.60$ & Complexity \\
\hline & Niutitang Formation & $20-200$ & $1.50-5.70$ & $2500-10000$ & I & $3.00-4.20$ & Complexity \\
\hline \multicolumn{2}{|c|}{ China Geological Survey standard } & $>15$ & $>2.00$ & $500-4500$ & & $0.50-3.50$ & \\
\hline
\end{tabular}




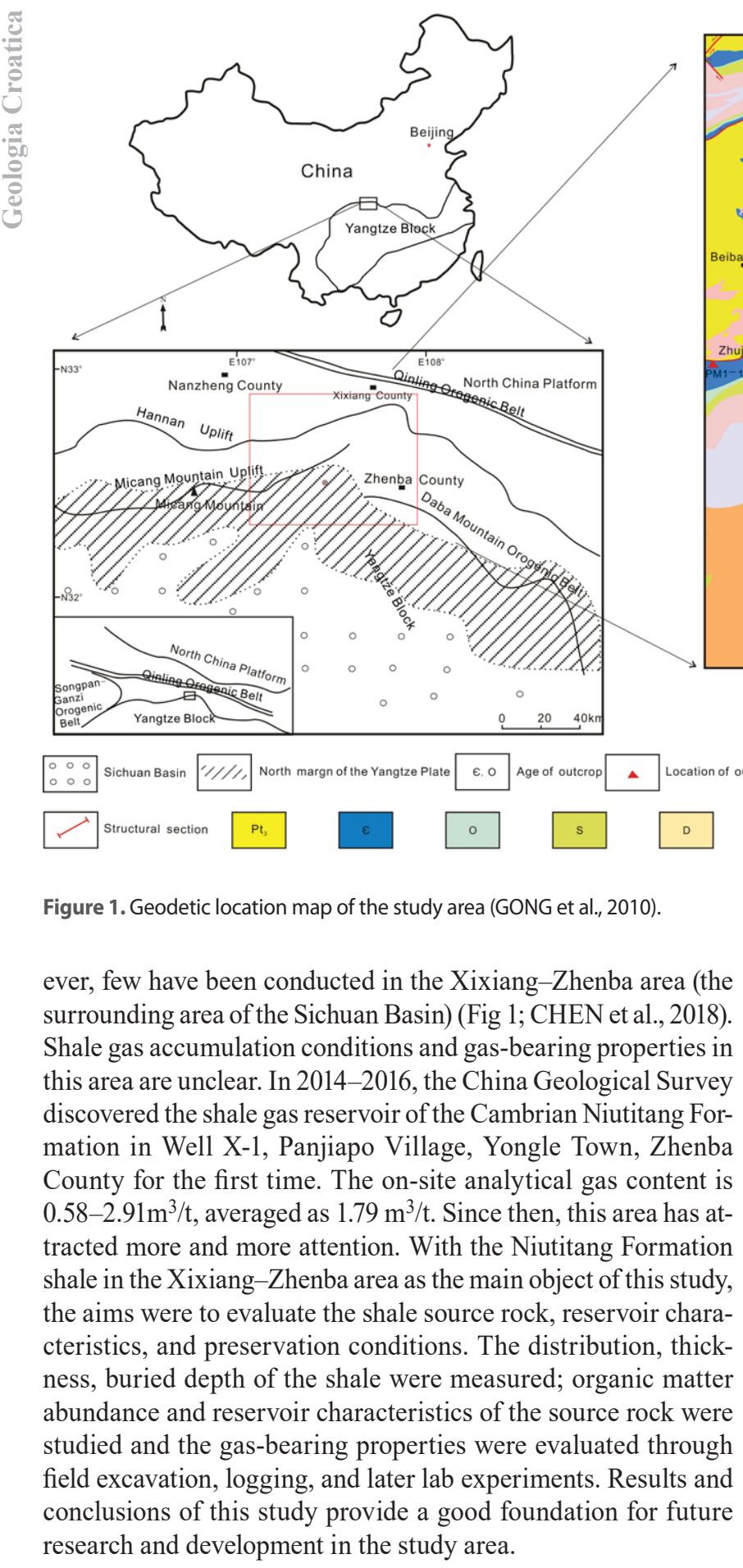

\section{GEOLOGICAL BACKGROUND OVERVIEW}

The study area is located on the northern margin of the Yangtze block in South China (Fig. 1). Geologically, the evolution of the Yangtze block can be divided into three stages over 2.5 billion years of history, from the Pre-Nanhua Period, through the Nanhua Period to the Middle Triassic (caprock deposit) Period, and the Late Triassic Period (HUANG \& SHEN, 2015). The basement consists of the Neoarchean-Palaeoproterozoic gneiss, mixed rocks, and metamorphic volcanic-sedimentary rocks of the Late Middle Proterozoic to the Early Neoproterozoic and intrusive complexes during the same period. The basement had been covered by the cap rock deposits of the platform since the Nanhua Period. It represents stable deposition in the epicontinental and marginal seas to the inland basin transformation, accompanied by the formation, reduction and subduction of the Shangdan Ocean to the North (LI, 2010 \& WU et al., 2013). The collision between the North and South China Plates caused intermittent overall uplift and erosion of the Yangtze block, resulting in the loss of Upper Cambrian, Upper-Middle Silurian, Devonian, and Carboniferous strata. The tectonic grid was mainly formed by the intraplate/land overlap A-type subduction in the IndosinianYanshan Period. It was also the result of long-term interaction between the Qinling orogenic belt, the Yangtze block, and the Songpan-Ganzi orogenic belt (Fig. 1).

The Lower Cambrian Niutitang Formation in the study area is located in the northeastern part of the outer margin of the Sichuan Basin, around the basement uplift of Hannan-Micang Mountain. Its administrative division is mainly located in Zhenba County, Xixiang County and parts of Nanzheng County.

\section{MATERIALS AND METHODS}

\subsection{SAMPLES}

Over 100 outcrop samples were collected at 8 sampling locations (sampling sections) in the Niutitang Formation. Sampling locations were located in well-exposed areas, mainly in Guanyin'an, Jiandongzigou and Zhujiaba (Fig. 1). Fresh and representative shale samples were selected for experimental analyses. Samples collected at outcrop sections were generally $3 \times 6 \times 9 \mathrm{~cm}$ in size. The total organic carbon (TOC) samples were collected every 3-5 $\mathrm{m}$ in the shale, and the remaining samples were collected every 10-40 m. More than 70 thin-sections were analysed, 50 samples were prepared for scanning electron microscope analysis and 4 samples were used for isothermal adsorption experiments.

\subsection{METHODS}

The total organic carbon was determined using a Total Organic Carbon Analyzer (multi-N/C3100-ZA310J). The total hydrocar- 
bon is the bulk composition of saturated hydrocarbon and aromatic hydrocarbon in the chloroform pitch "A"(EOM). It was obtained by chloroform asphalt extraction using the Soxhlet Extraction method. The rock samples were pulverized into powder with a particle size of less than $0.09 \mathrm{~mm}$, and then continuously steamed with chloroform under boiling temperatures (generally $80^{\circ} \mathrm{C}$ ) to extract the soluble organic matter in the rock.

The vitrinite reflectance (Ro) and maximum temperature of the Rock Eval pyrolysis (Tmax) were used to evaluate organic matter maturity. Ro was detected using a Microscope Photometer (MPV-3), and Tmax was measured using a Rock Pyrolysis Analyzer (OGE-VI).

The kerogen type of the Niutitang Formation shale was determined using the kerogen TI index (CAO, 1985), kerogen carbon isotope ratio and $\mathrm{H} / \mathrm{C}$ and $\mathrm{O} / \mathrm{C}$ atomic ratios of the kerogen. The TI $=($ Sapropelite, $\% \times 100+$ Exinite,$\% \times 50$-Vitrinite, $\% \times 75$ Inertinite, $\% \times 100) / 100$ ) and kerogen carbon isotope were detected by using Multi-Collector Inductively-Coupled Plasma Mass Spectrometry(MC-ICP-MS), and the organic elements in the kerogen were observed using the element analyzer (Flash-IRMS) and stable isotope mass spectrometer (Delta V Advantage).

The mineralogical characterization of shale samples was carried out using an X-ray diffractometer (XRD, D/max-2500v). To obtain the microscopic pore characteristics, shale samples were observed using Scanning Electron Microscopy (SEM, JIB-4500) and an Electron Probe Micro-analyzer (EPMA, Japan-JEOLJXA-8230).

Taking Well X-1 as an example, after obtaining the on-site analytical gas content, the residual gas content was measured in the laboratory. In addition, the lost gas content was calculated by linear regression, with the total gas content being obtained by summing these three components. This procedure was carried out by the China Geological Survey in 2014. The TOC content of the shale was estimated from the positive correlation between the total gas content and the TOC content (REEDR et al., 2007).

An Isothermal adsorption experiment was used to simulate the adsorption process of the shale using an isotherm instrument (GAI100-ZA306M). The relationship model of the adsorption gas content with regard to pressure and temperature was established and then gas content was obtained. This can also be used to verify

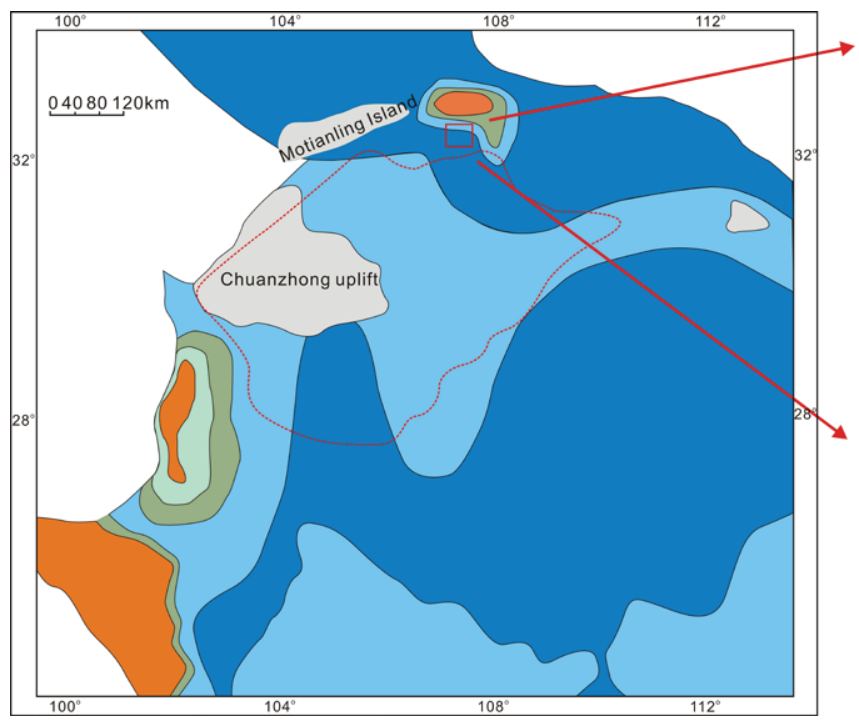

the relationship between the amount of adsorption and total organic carbon. The methodology of the isothermal adsorption experiment was as follows. The shale samples were pulverized and heated to remove the adsorbed natural gas. They were then placed in a sealed container and the pressure was continuously increased under a constant temperature $\left(25^{\circ} \mathrm{C}\right)$. The amount of the adsorbed natural gas was measured and the measurements were fitted to the Langmuir equation to form an isothermal adsorption curve.

\section{RESULTS AND INTERPRETATION}

\subsection{SEDIMENTARY ENVIRONMENT}

During the Early Palaeozoic sea level rose rapidly, whereby the Sichuan Basin and surrounding areas were generally open continental shelf environments. The west side of these areas was dominated by uplift of the Chuanzhong, and Motianling Island was located to the north. The distribution of the sedimentary facies in the southeast of the areas was the shore facies-shallowwater shelf facies-deep-water shelf facies (Fig. 2). Water depth around the ancient land increased and the nearshore coastal zone was less preserved due to the transgression of the Niutitang Period. During the transgression, shallow-water shelf facies prograded in the middle and late stages of the Early Palaeozoic.The Micang Mountain strata, in the west of the study area (Fig. 1), evolved from the Late Sinian-Chinese stratigraphic age-Dengying Period to the Early Cambrian Niutitang Period and were represented by continuous deposition. This led to the integrated contact of the Dengying Formation with the Niutitang Formation (Fig. 3). With expansion of the marine transgression from the southeast to the northwest, the Niutitang Formation overlapped westward. Due to gradual uplift the formation is absent in the northwest of the Hannan uplift (Fig. 1), resulting in the unconformable contact of the Shipai Formation over the Dengying Formation. In the study area two major sedimentary subfacies developed; the deep-water shelf subfacies and the shallowwater shelf subfacies (Fig. 2). The boundary of these two subfacies is located to the west of Zhenba County and east of Bashan Forest Farm (Fig. 1) and runs approximately northsouth. The shallow-water shelf was developed in the east, and the deep-water shelf to the west of the boundary. The shale thickness and organic matter content of the deep-water shelf are

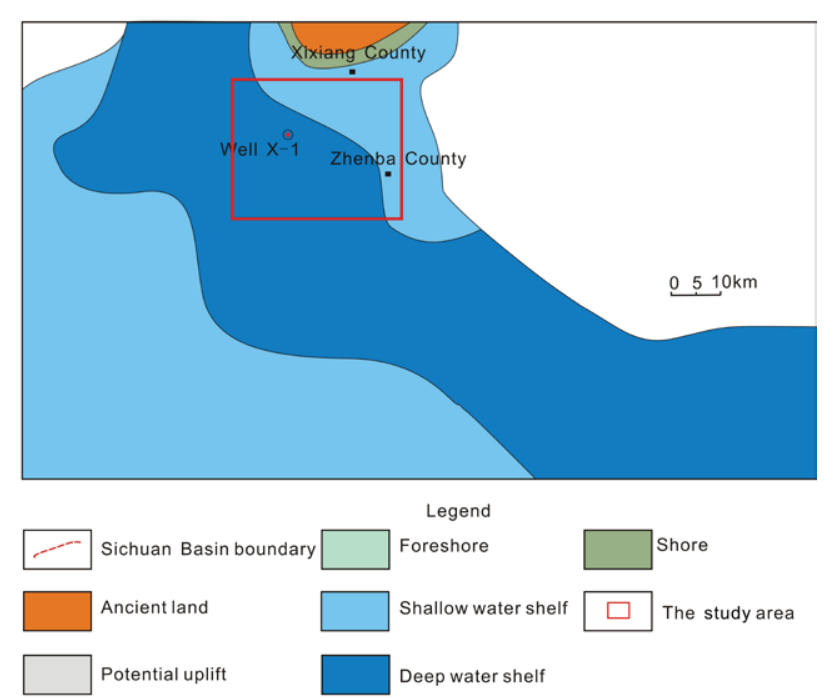

Figure 2. Sedimentary facies of the Sichuan Basin and the Niutitang Formation study area (MU et al., 2011). 


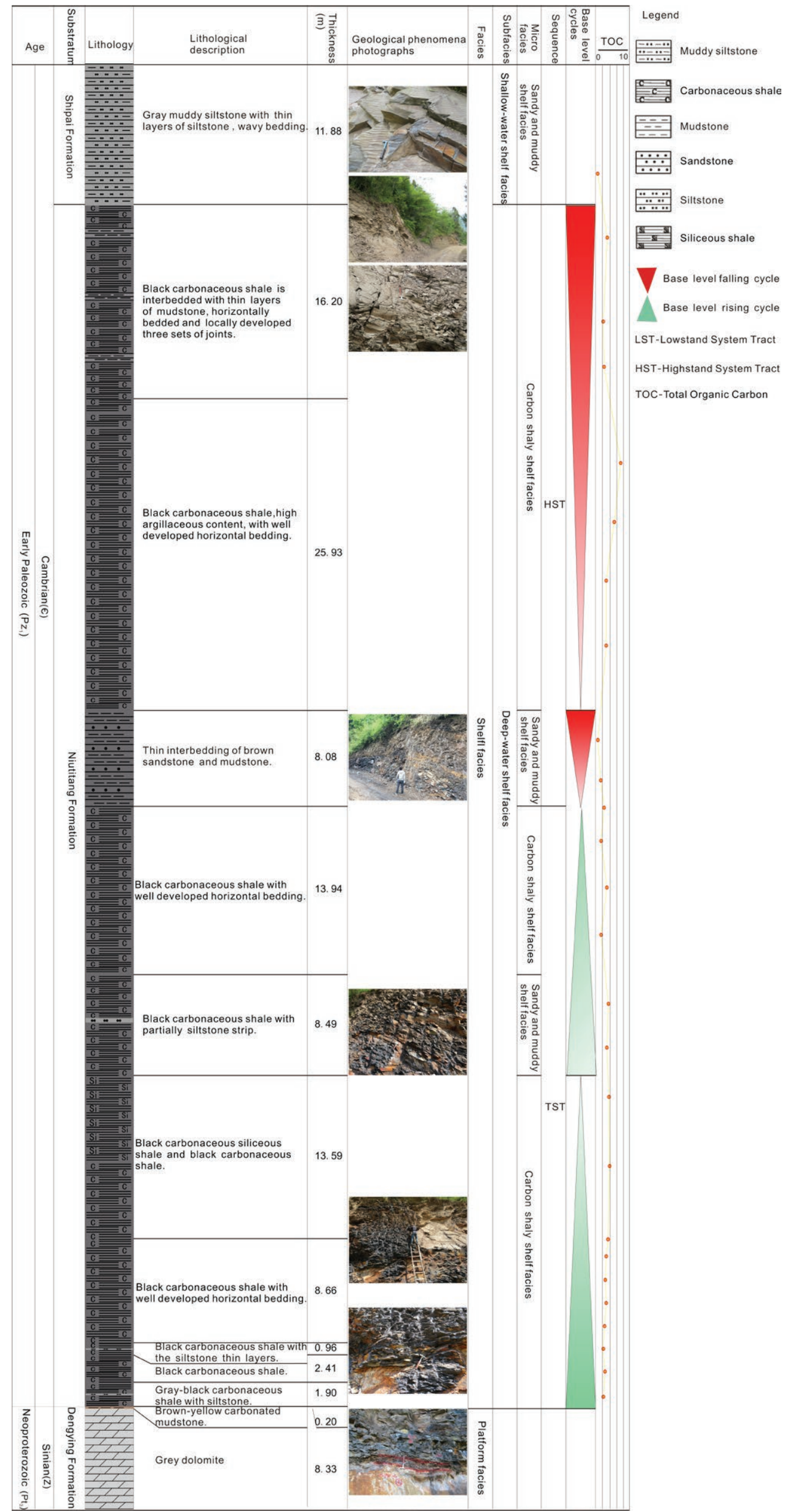

Figure 3. Typical litho-stratigraphic section and sedimentary facies of Xixiang area and its substratum. 


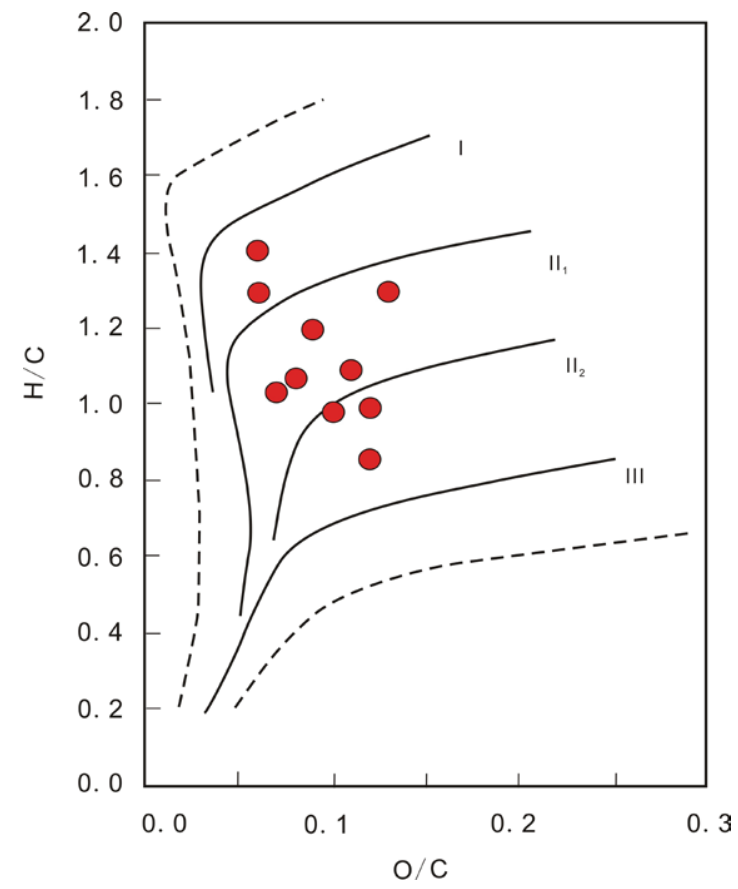

Figure 4. Van Krevelen diagram of the samples.

higher than those of the shallow-water shelf, which is also consistent with the results of the sedimentary facies distribution (DONG et al., 2010; WANG et al., 2012; GUO et al., 2014).

\subsection{SOURCE ROCK CHARACTERISTICS}

\subsubsection{SHALE DISTRIBUTION CHARACTERISTICS}

Lower Palaeozoic marine shale developed in southern China has a good material basis for the formation of large oil and gas fields

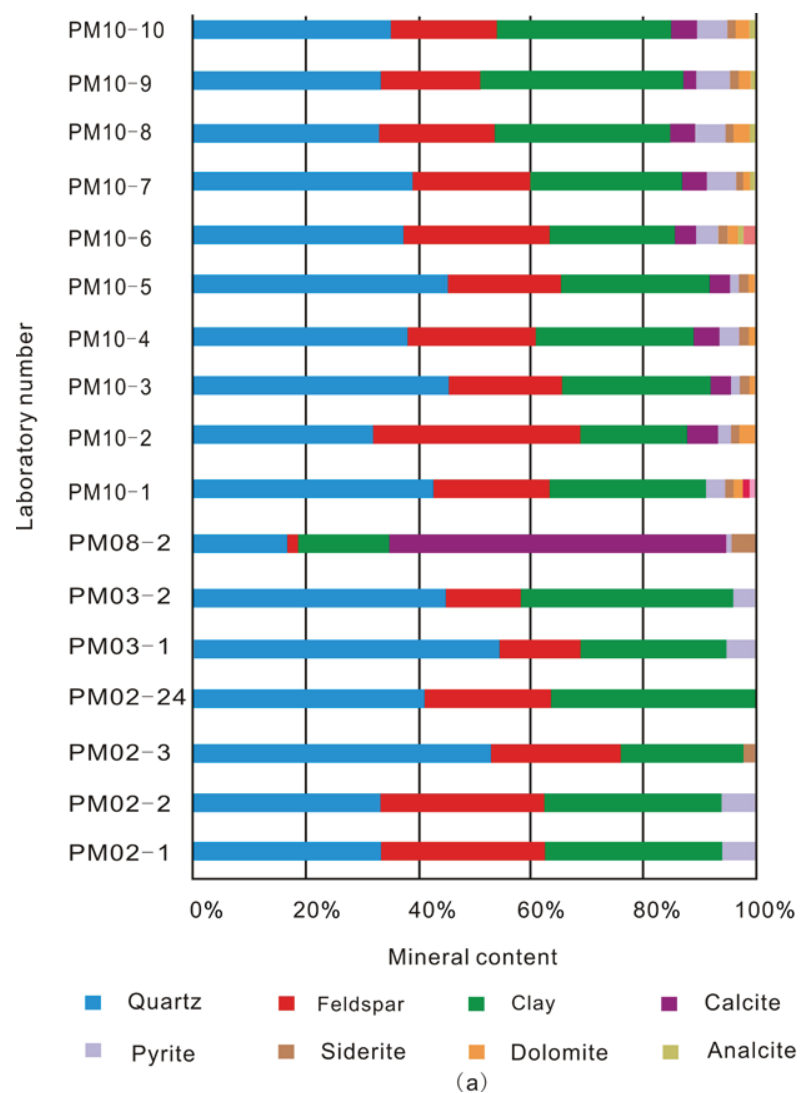

Figure 5. The mineral composition and clay content of the samples.
(Fig. 3). It is generally believed that the Lower Palaeozoic marine shale is the most important source rock in South China and has a good shale gas exploration prospect (ZHOU et al., 1999; MAO et al., 2006; ZHANG et al., 2008; LI et al., 2013; SHEN et al., 2017). The black shale of the Niutitang Formation in the study area is mainly located at Dahe Town in Xixiang County, Gaoqiao Village, Xiaoyangba, Ping'an chang and Xingzi Mountain areas of Zhenba County, Fucheng Town and the town of Beiba in Nanzheng County (Fig. 1).

The Niutitang Formation is mainly composed of black carbonaceous shale, silty shale, and black carbonaceous siliceous shale with siltstone and marl. The shale and siltstone form very fine horizontal bedding. The distribution of the dust-like pyrite is often along the bedding plane and pyrite nodules are also very common. The shale thickness is mainly $10-110 \mathrm{~m}$, from south to north, and its thickness increases from east to west. High quality source rocks are mainly distributed in the Fucheng and Dahe towns in the west, with a thickness of $80-100 \mathrm{~m}$ (Fig. 1). The carbonaceous shale of the Niutitang Formation reduces from east to west, and it reflected the shallowing characteristics of the water level, which was also consistent with the characteristics of the sedimentary facies.

\subsubsection{GEOCHEMICAL CHARACTERISTICS OF ORGANIC MATTER 4.2.2.1. ABUNDANCE OF ORGANIC MATTER}

Abundance of organic matter is one of the most important indicators for evaluating shale source rocks. The total organic carbon and total hydrocarbon content (saturated hydrocarbons and aromatics content) are common indicators for evaluating the abundance of shale organic matter (BURNAMAN \& SHELTON, 2009). Results from more than 60 outcrop samples, show the TOC of the Niutitang Formation ranges from $0.25 \%$ to $9.45 \%$, with an average of $2.93 \%$. The TOC of the western shale area is generally

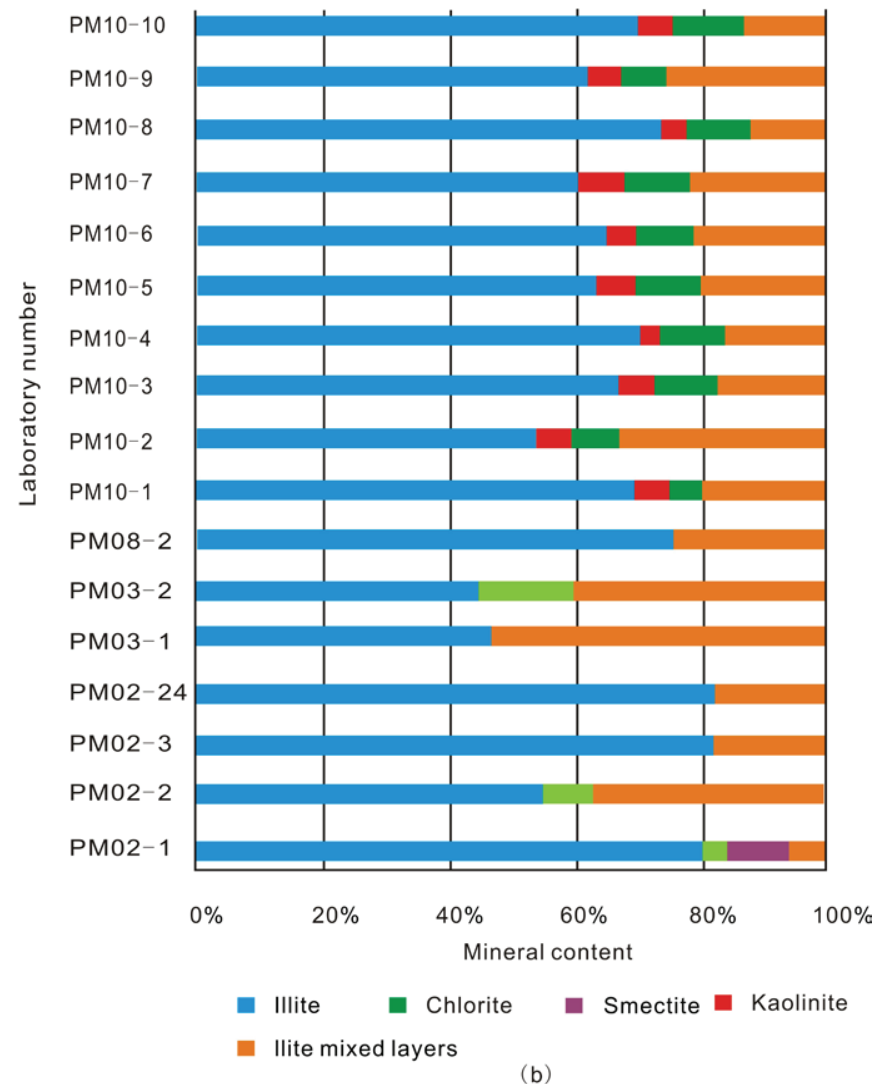

(b)

\section{$\frac{1}{8}$}


Table 2. Clay mineral relative content test results for the samples.

\begin{tabular}{|c|c|c|c|c|c|c|c|c|}
\hline \multirow[t]{2}{*}{ Number } & \multicolumn{6}{|c|}{ Clay mineral content (\%) } & \multicolumn{2}{|c|}{$\begin{array}{c}\text { Mixed layer of } \\
\text { illite and smectite } \\
\text { content (\%) }\end{array}$} \\
\hline & Smectite & Illite & Kaolinite & Chlorite & $\begin{array}{c}\text { Illite/ } \\
\text { smectite }\end{array}$ & $\begin{array}{l}\text { Chlorite/ } \\
\text { smectite }\end{array}$ & $\begin{array}{c}\text { Smectite } \\
\text { layer }\end{array}$ & $\begin{array}{l}\text { Illite } \\
\text { layer }\end{array}$ \\
\hline PM02-1 & 10 & 80 & 0 & 4 & 6 & 0 & 65 & 35 \\
\hline PM02-2 & 0 & 55 & 0 & 8 & 37 & 0 & 10 & 90 \\
\hline PM02-3 & 0 & 82 & 0 & 0 & 18 & 0 & 10 & 90 \\
\hline PM02-24 & 0 & 82 & 0 & 0 & 18 & 0 & 10 & 90 \\
\hline PM03-1 & 0 & 47 & 0 & 0 & 53 & 0 & 10 & 90 \\
\hline PM03-2 & 0 & 45 & 0 & 15 & 40 & 0 & 10 & 90 \\
\hline PM08-2 & 0 & 93 & 0 & 0 & 7 & 0 & 5 & 95 \\
\hline PM10-1 & 0 & 71 & 4 & 5 & 20 & 0 & 65 & 35 \\
\hline PM10-2 & 0 & 54 & 5 & 9 & 32 & 0 & 10 & 90 \\
\hline PM10-3 & 0 & 67 & 6 & 10 & 17 & 0 & 10 & 90 \\
\hline PM10-4 & 0 & 70 & 4 & 10 & 16 & 0 & 10 & 90 \\
\hline PM10-5 & 0 & 64 & 6 & 10 & 20 & 0 & 10 & 90 \\
\hline PM10-6 & 0 & 66 & 4 & 9 & 21 & 0 & 10 & 90 \\
\hline PM10-7 & 0 & 61 & 7 & 10 & 22 & 0 & 10 & 90 \\
\hline PM10-8 & 0 & 74 & 4 & 10 & 12 & 0 & 10 & 90 \\
\hline PM10-9 & 0 & 63 & 5 & 7 & 25 & 0 & 10 & 90 \\
\hline PM10-10 & 0 & 70 & 6 & 11 & 13 & 0 & 10 & 90 \\
\hline
\end{tabular}

greater than $1 \%$ (mostly between $2 \%$ and $6.5 \%$ ), with an average of $3.66 \%$. The TOC of $69.81 \%$ samples ranges from $2 \%$ to $4 \%$, indicating organic-rich shales. The content of saturated hydrocarbons and aromatics in extracts from the shale ranges from $12.63 \%$ to $55.90 \%$, with an average of $31.54 \%$, the total hydrocarbon content is mainly $100-1500 \mathrm{ppm}$. In general, the shale of the Niutitang Formation is rich in organic matter, which provides a good material basis for a shale gas reservoir.

\subsubsection{TYPE OF ORGANIC MATTER}

The shale kerogen contains a large amount of the macerals of the sapropelite group (more than 93\%), and a small amount of macerals of the vitrinite group. The kerogen TI index method (TI > 80, kerogen type I) reveal that the shale kerogen of the Niutitang Formation is of type I. The shale kerogen carbon isotope value $\mathrm{d}^{13} \mathrm{C}$ ranges from -33.5 to $-33.06 \%$. The shale kerogen type is mainly type $\mathrm{I}$. The kerogen $\mathrm{H} / \mathrm{C}$ and $\mathrm{O} / \mathrm{C}$ atomic ratios range from
0.46 tol.48 (average 1.07) and from 0.06 to 0.33 (average 0.12), respectively. The shale kerogen type is mainly type I and II (Van Krevelen diagram, Fig. 4). Based on all the results obtained, the kerogen of the Niutitang Formation shale is of type I and II, types that are favourable for hydrocarbon generation.

\subsubsection{MATURITY OF ORGANIC MATTER}

Thermal maturity is the basis for evaluating the hydrocarbon generation potential of the source rocks. Maturity is mainly evaluated by vitrinite reflectance (Ro) and the maximum temperature of the Rock Eval pyrolysis (Tmax). The Ro is between $2.14 \%$ and $2.84 \%$, with an average of $2.51 \%$, so generally greater than $2 \%$. The organic matter is mainly in the over mature stage of thermal alteration. The Tmax of the kerogen is mainly between $486^{\circ} \mathrm{C}$ and $569^{\circ} \mathrm{C}$, with a maximum of $584^{\circ} \mathrm{C}$ indicating a high-over mature stage. Based on Ro and Tmax, the maturity of the organic matter is in the high-over maturity stage.

\subsection{RESERVOIR CHARACTERISTICS}

According to geochemical characteristics, the Niutitang Formation shale is a high quality source rock, but whether it is a good reservoir is also very important for shale gas reservoir formation (VELIĆ et al., 2012). Based on the test in Well X-1, the gas content of the Niutitang Formation shale is high, and there are clearly reservoir conditions and some exploration potential indicated.

\subsubsection{ROCK MINERALOGICAL CHARACTERISTICS}

Mineral X-ray diffraction analysis of the black shale samples shows that the black shale consisted mainly of quartz, clay, feldspar, and a small amount of pyrite, siderite and carbonate minerals. The quartz content is greatest from $30 \%$ to $54 \%$, (average $38 \%$ ); clay content ranges from $9 \%$ to $38 \%$, (average $25 \%$ ); with $13 \%$ to $38 \%$ feldspar (average $27 \%$, of which K-feldspar is $0 \%-7 \%$, (average $4 \%$ ); plagioclase $12 \%-34 \%$, (average $23 \%$ )). Pyrite content varies from $0 \%$ to $6 \%$, (average $3 \%$ ); and the siderite content is the smallest, from $0 \%$ to $2 \%$, (average $1 \%$ ) (Fig. 5a). The content of the brittle minerals is high, meaning that it can easily be broken by external force to form cracks. The possibility of shale fracturing is beneficial to the exploitation of the shale gas (LIU, 2012).

The clay minerals of the shale samples are mainly illite, followed by a mixed layer of illite and smectite and a small amount of smectite and chlorite (Table 2, Fig. 5b). The illite content varies
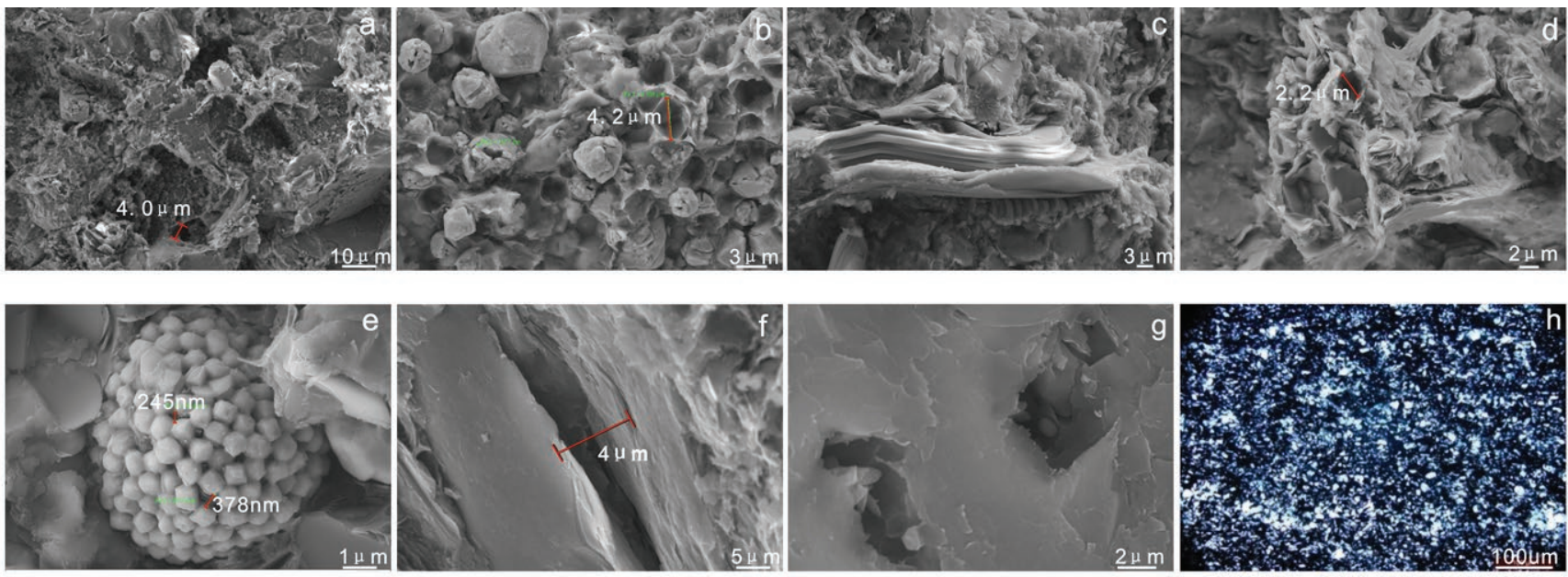

Figure 6. Microstructural features of the samples. (a) Dissolution pores of calcite/dolomite particles; (b) Casting-mold pores formed by the dissolution of pyrite and the residual pyrite particles; (c) Linear pores; (d) Intergranular pores between clay mineral particles; (e) Pores between the pyrite crystals; (f) Microfractures; (g) Organic pores; (h) Oriented quartz particles. 
between $45 \%$ and $93 \%$, with an average of $69.1 \%$; the content of mixed layer of illite and smectite is between $6 \%$ and $53 \%$, with an average of $25.6 \%$; and the content of the chlorite and smectite is $5.3 \%$. The mixed layer illite and smectite is mainly the illite layer, which accounts for $35 \%$ to $95 \%$, with an average of $82.9 \%$. SCHETTLER et al. (1990) showed that the adsorbed methane in the shale was mainly distributed on the surface of the clay mineral illite and then in kerogen. LU et al. (1995) determined that the illite in clay minerals was particularly important for the adsorption of shale gas in shales with low organic carbon content. The higher content of illite in the shale of the Niutitang Formation is beneficial for improving the adsorption performance of the shale and the preservation of the adsorbed gas (WANG et al., 2017).

\subsubsection{RESERVOIR PORE SPACE TYPE AND PORE STRUCTURE CHARACTERISTICS}

The results of SEM and EPMA have shown that the pores and microcracks of the Niutitang Formation shale are relatively well developed. The pore types include the intragranular pores, intergranular pores and organic pores, providing good spaces for shale gas accumulation (JARVIE et al., 2007; YU, 2013; SHAO et al., 2019).

The intragranular pores developed inside the particles or crystals. Most of them were triangular/quadrangular and distributed in a scattered pattern. The pore size is in nanometres to micrometres. The intragranular pores mainly include the following: (1) dissolution/mold pores formed by the partial/complete dissolution of particles (Fig. 6a, b), the pore size can reach micron levels; (2) linear pores along the cleavage of mica and clay flakes or plates (Fig. 6c); these pores are mostly less than $1 \mu \mathrm{m}$; (3) pores within fossils; and (4) internal pores of other particles, such as spherulite. The intergranular pores mainly appear between the mineral particles, including the intercrystalline pores, pores between clay mineral particles, and the marginal pores of rigid particles. A large number of the pores occur between clay mineral particles and are intercrystalline pores of the Niutitang Formation shale (Fig. 6d, e), the intercrystalline pores of pyrite have a smaller pore size, mainly between 200 and $400 \mathrm{~nm}$. Most of the microfractures in the shale samples were developed in organic matter (Fig. 6f). A small number of organic pores developed in the shale of the Niutitang Formation (Fig. 6g).

\subsubsection{RESERVOIR POROSITY AND PERMEABILITY CHARACTERISTICS}

In unconventional oil and gas reservoirs, porosity and permeability are the main parameters of reservoir evaluation, as they directly affect the gas content and the exploration potential of the shale gas. In particular, the permeability is an important parameter for assessing the industrial value of the shale oil and gas development. The shale generally has the characteristics of poor permeability, strong compactness, and strong heterogeneity. The effective porosity of the shale in the study area is $3.5 \%-7.2 \%$, (average $5.35 \%$ ). The permeability is mainly distributed between $0.011-$ $0.028 \times 10^{-3} \mu \mathrm{m}^{2}$, (average $0.0195 \times 10^{-3} \mu \mathrm{m}^{2}$ ). Therefore, the Niutitang Formation shale is a low porosity and permeability reservoir.

\subsubsection{DIAGENESIS}

The common diagenesis in the shale mainly includes the compaction, cementation, dissolution, organic matter maturation, and transformation of clay minerals. However, these surface outcrop samples were subject to greater oxidation and eluviation than well samples would. Recognition of mineral morphology under scanning electron microscope is low. Combined with the qualitative analysis of the electron probe, it is believed that the diagenesis types of the Niutitang Formation in the study area mainly included compaction, dissolution and organic matter maturation.

Compaction is the main type of shale diagenesis, accompanied by the entire process of sedimentary diagenesis. Shale has relatively weak resistance to compaction because of the presence of clay minerals. Under compaction, the clay grain frame will gradually deform, the porosity will decrease, and the interlayer water will greatly reduce. Compaction is one of the main reasons for densification of the Niutitang Formation shale in the XixiangZhenba area (VELDE, 1996; KONG et al., 2016). The identification indicators of compaction are mainly orientation arrangement of mineral particles to a certain extent in the Niutitang Formation shale samples (Fig. 6h), but the orientation is not obvious due to the complicated geological movement experienced in the later periods. Dissolution is related to acidic water or organic acids produced during the maturation process of the organic matter. When these acidic fluids are in contact with soluble components (feldspar or carbonate minerals), dissolution occurs, forming a large number of dissolution pores, which are beneficial for increasing the porosity of the shale. In addition, the maturation of organic matter produced a small number of organic pores, most
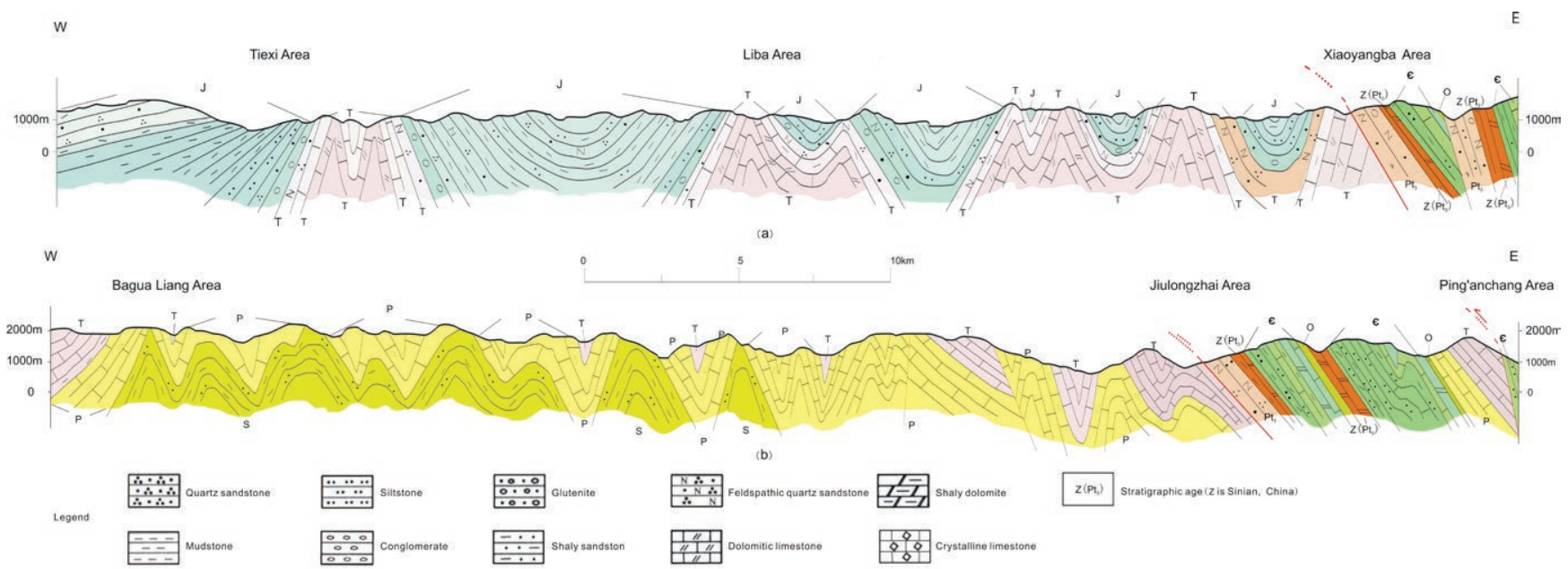

Figure 7. (a) Comb-like folds in the south; (b) Trough-like folds in the northeast (CHEN et al., 2008). 


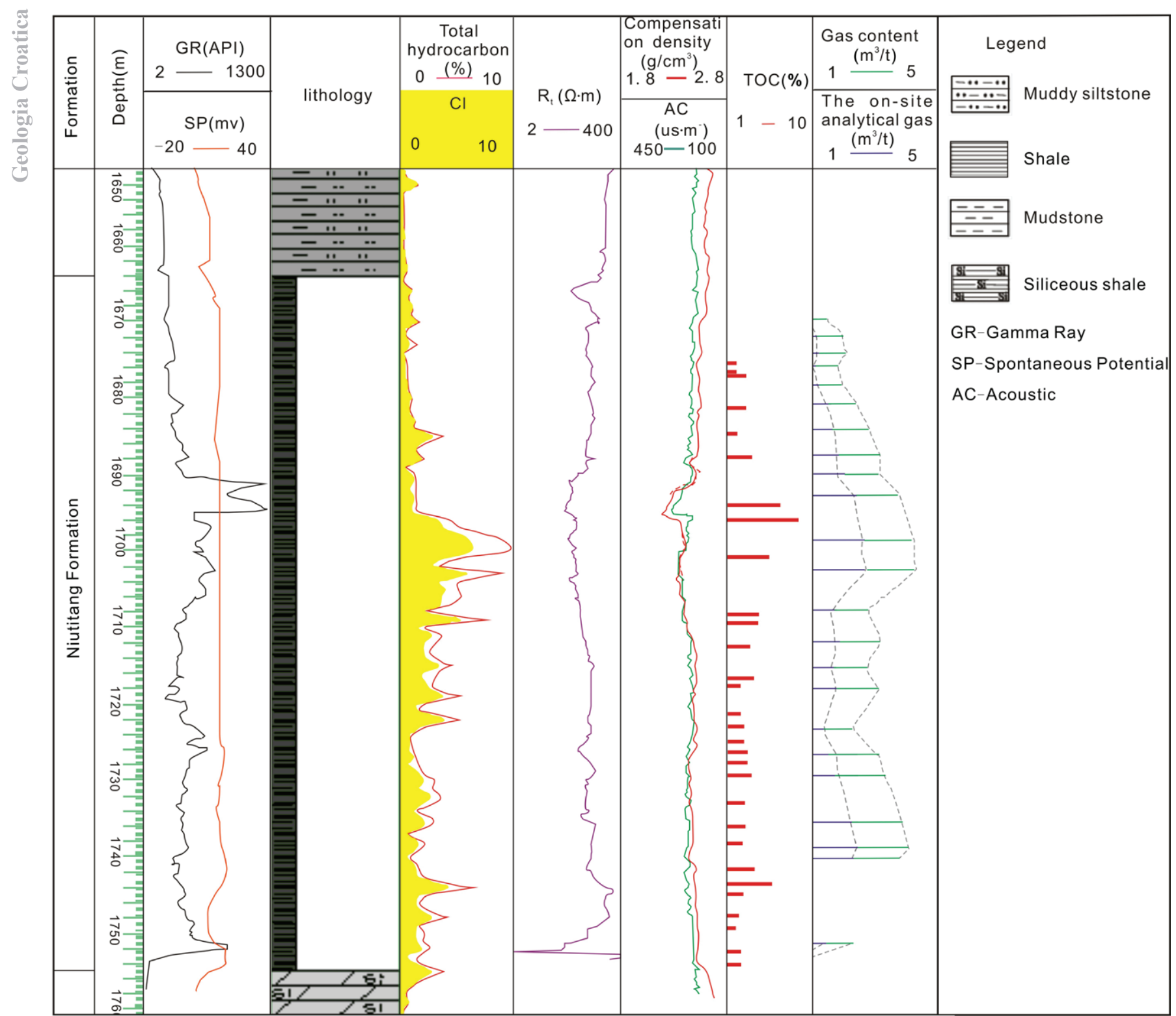

Figure 8. Column diagram of the Well X-1 (China Geological Survey, 2014).

of which are residual pores during hydrocarbon generation observed under a microscope (Fig. 6g).

\subsection{PRESERVATION CONDITIONS}

The preservation conditions directly affect the shale gas volume and composition of the shale gas reservoirs (WANG et al., 2009). The buried depth of the Niutitang Formation shale is mainly $1500-4500 \mathrm{~m}$, and the underlying strata is dolomite of the Sinian Dengying Formation of Sinian Age, with a poor preservation condition; the overlying strata is the muddy siltstones and the siltstone of the Cambrian Shipai Formation with good reservoir seal qualities (Fig. 3). The Hannan-Micang Mountain uplift is to the west of the area, and the stratum itself is relatively stable. Comblike folds are distributed in the south, with weak deformation (Fig. 7a). Trough-like folds are distributed in the northeast, with strong stratum deformation, and the degree of deformation weakens from east to west (Fig. 7b). The middle part is the transition area between the trough-like folds and comb-like folds, and the deformation is not strong. At present, the shale gas reservoirs discovered in the Sichuan Basin and surrounding areas are mainly located in this transition area, such as the Fuling shale gas reservoir (SUN \& LUO, 2016; WEI et al., 2019). Therefore, the structural preservation conditions in the western, central, and southern regions of the study area are better.

\subsection{SHALE GAS-BEARING CAPACITY}

The China Geological Survey drilled the Well X-1 in Zhenba County, to a total depth of $1772 \mathrm{~m}$. This resulted in the first discovery of the Cambrian Niutitang Formation shale gas reservoir in the study area, and the shale of the Niutitang Formation was drilled accumulatively for $90 \mathrm{~m}$. The on-site analytical gas content $<2.92 \mathrm{~m}^{3} / \mathrm{t}$, the total gas content is $<6.04 \mathrm{~m}^{3} / \mathrm{t}$, and a high-quality shale (TOC $>2 \%$ ) is mainly developed in the upper middle and lower middle parts of the Niutitang Formation (depths $1688-1717 \mathrm{~m}$, 1726.5-1477m). The well log curves have high-natural gamma, high-acoustic, low-density, and low-resistance characteristics (Fig. 8). The Zhenba area is listed as one of the most favourable areas in the Sichuan Basin and surrounding areas, with a natural gas commercial exploitation value (China Geological Survey, 2014). 

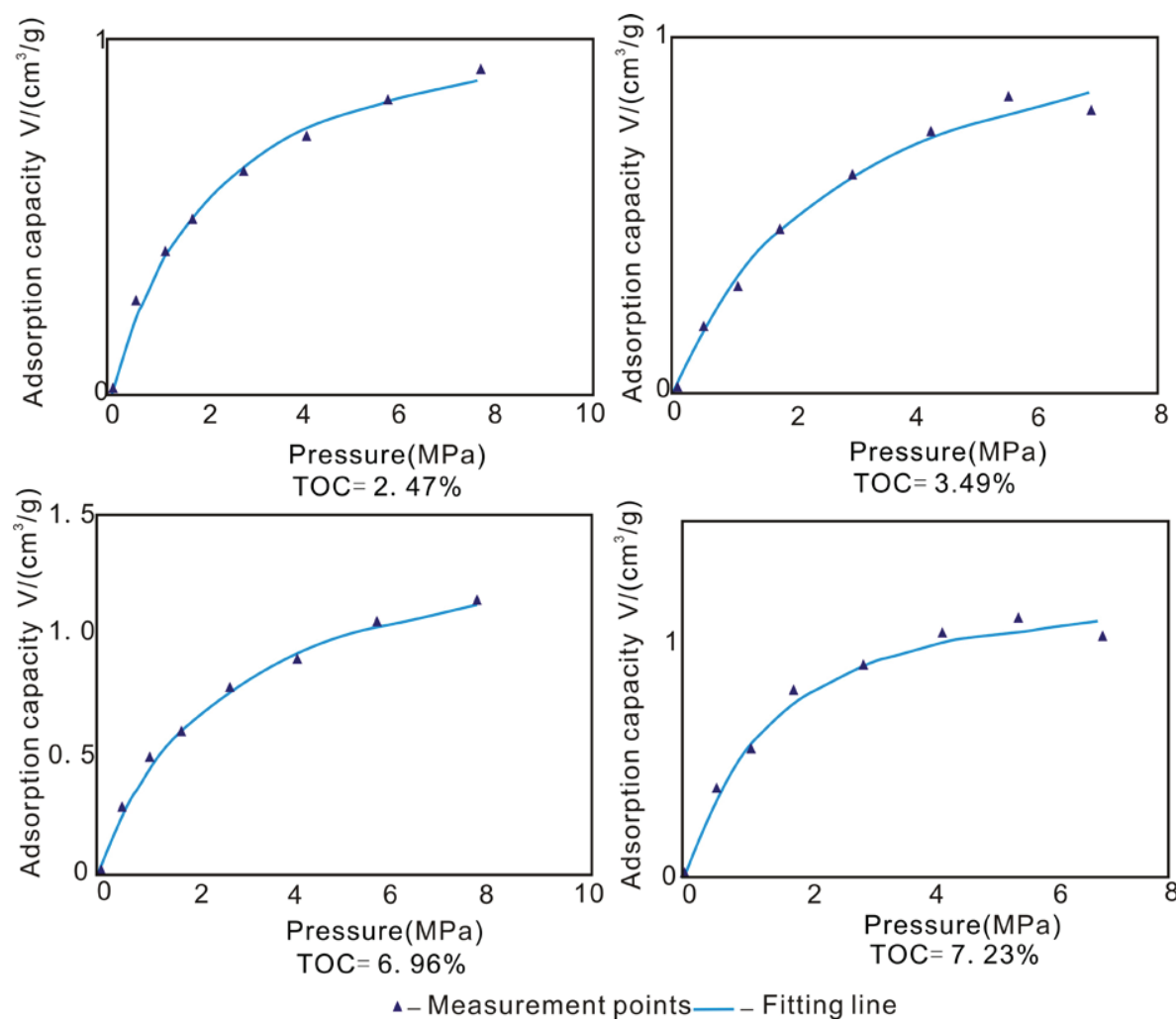

Figure 9. Isothermal adsorption experiments of the shale samples.

The shale gas is present in the shale in the adsorption state. At present, the isothermal adsorption simulation method is often used to determine the adsorption capacity of shale, so as to obtain the gas content of shale. The method needs to establish a relationship model between the adsorption gas content and pressure and temperature. Using the following formula:

$$
\mathrm{V}_{\mathrm{a}}=\mathrm{V}_{\mathrm{L}} \times \mathrm{P} /\left(\mathrm{P}+\mathrm{P}_{\mathrm{L}}\right)
$$

Where $\mathrm{V}_{\mathrm{a}}$ is the calculated adsorption gas content, $\mathrm{m}^{3} / \mathrm{t} ; \mathrm{V}_{\mathrm{L}}$ is the Langmuir volume, $\mathrm{m}^{3} / \mathrm{t} ; \mathrm{P}_{\mathrm{L}}$ is the Langmuir pressure, Mpa; and $\mathrm{P}$ is the stratum pressure, Mpa.

According to the results of the isothermal adsorption experiment, the saturated adsorption capacity of the Niutitang Formation shale is $0.61-1.15 \mathrm{~m}^{3} / \mathrm{t}$, indicating that it has a high adsorption capacity. It was discovered that the higher the shale pressure, the higher the adsorption gas content, and the two are positively correlated. At the same time, the maximum adsorption gas content and TOC content of the shale are also closely related. As shown in Figure 9, the shales with the TOC of $2.47 \%, 3.49 \%, 6.96 \%$ and $7.23 \%$ have the saturation adsorption capacity of $0.92 \mathrm{~m}^{3} / \mathrm{t}, 0.61$ $\mathrm{m}^{3} / \mathrm{t}, 1.01 \mathrm{~m}^{3} / \mathrm{t}$ and $1.15 \mathrm{~m}^{3} / \mathrm{t}$, respectively. Generally, the higher the TOC content of the sample, the higher the adsorption capacity. Combined with previous research results (CHEN et al., 2018), the sample TOC is considered to be proportional to the maximum adsorbed gas content. In summary, the shale in the Niutitang Formation of the study area has high gas content, and the gas-bearing potential of the shale could be roughly evaluated using the TOC content result.

\section{CONCLUSIONS}

The following conclusions are drawn from this study:

(1) In the Niutitang Formation in the study area, two sedimentary subfacies, namely the deep-water shelf subfacies and the shallow-water shelf subfacies are developed. Black carbonaceous shale, silty shale, and black carbonaceous siliceous shale with siltstone and marl prevailed.

(2) In the study area, the thickness of the shale increases from south to north, from east to west, high quality source rocks are mainly distributed in the Fucheng and Dahe areas. Black carbonaceous shale is the organic rich source rock in higher maturity stage of thermal transformation (high-over mature stage of thermal evolution). The source rock mostly contains kerogen type I and II, kerogen that is favourable for hydrocarbon generation.

(3) The reservoir has a high content of brittle minerals and cracks. The clay mineral content is relatively low, mainly illite, followed by the mixed layer of illite and smectite, which is beneficial for the adsorption performance of the shale. The pore types mainly included intragranular pores, intergranular pores, and organic pores, providing good spaces for the storage of shale gas. The gas shale reservoir has low permeability and low porosity. The western, central, and southern regions of the study area have good preservation conditions.

(4) The shale gas reservoir in the Niutitang Formation has good reservoir-forming conditions, and the shale has a high adsorption capacity. It also has a good gas-bearing property, indicating a certain resource potential. These findings are a good foundation for future research and development work in this area.

\section{ACKNOWLEDGEMENT}

The authors would like to acknowledge the "Project on Shale Gas Geological Survey in Xixiang-Zhenba Area, Shaanxi Province (project no. 20170104)", and "Research Project on Occurrence Law of the Tar-rich Coal and Its Beneficial Mineral Resources in Shaanxi Province, China (project no. 20180304)", which collectively funded this project. 


\section{REFERENCES}

BURNAMAN, M.D. \& SHELTON, J. (2009): Shale gas play screening and evaluation criteria.- China Petroleum Exploration, 14/3, 51-164.

BERMAN, A.E. (2009): Shale plays and lower natural gas prices: A time for critical thinking.- World Oil, 230/1, 15.

CURTIS, J.B. (2002): Fractured shale-gas systems.-AAPG Bulletin, 86/11, 1921-1938. doi: 10.1306/61eeddbe-173e-11d7-8645000102c1865d

CHEN, X.L., ZHAI, G.Y., BAO, S.J., PANG, F., WANG, J.Z. \& TONG, C.C. (2018): Shale gas accumulation and gas-bearing properties of Niutitang Formation in well Zhendi 1, Zhenba region of southern Shaanxi Province.-China Mining Magazine, 27/b06, 101-106.

CAO, Q.Y. (1985): Identification of microcomponents and types of kerogen under transmitted light - Petroleum Exploration and Development, 6/5, 14-24.

CHEN, G.C., ZHANG, J.L., WANG, Z.C., DONG, H.B. \& CHEN, J.Y. (2008): Regional geological survey map of Nanjiang area (geological map 1:1250,000).-Shaanxi Mineral Resources and Geological Survey.

DURHAM, L.S. (2005): Barnett shale play still going strong.- AAPG Explorer, 4-6 p.

DONG, D.Z., CHENG, K.M., WANG, Y.M., LI, X.J., WANG, S.J. \& HUANG, J.L. (2010): Forming conditions and characteristics of shale gas in the Lower Palaeozoic of the Upper Yangtze region China.- Oil \& Gas Geology, 31/3, 288-299. doi: 10.11743/ogg20100304

GONG, D.X., LIN, J.H., TANG, Y.F., WU, C.H. \& SONG, H.Y. (2010): Organic geochemical characteristics of Palaeozoic marine source rocks in northern margin of the Upper Yangtze Platform.- Lithologic Reservoirs, 22/3, 31-37. doi: 10.3969/j. issn.1673-8926.2010.03.007

GUO, X.S., HU, D.F., WEN, Z.D., JIANG, S.L. \& WANG, Z.Y. (2014): Major factors controlling the accumulation and high productivity in marine shale gas in the Lower Palaeozoic of Sichuan Basin and its periphery: A case study of the WufengLongmaxi Formation of Jiaoshiba area.- Geology in China, 41/3, 893-901. doi: 10.3969/j.issn.1000-3657.2014.03.016

HU, M.Y., DENG, Q.J. \& HU, Z.G. (2014): Shale gas accumulation conditions of the Lower Cambrian Niutitang Formation in the Upper Yangtze region.- Oil \& Gas Geology, 35/2, 272-279. doi: 10.11743/ogg20140215

HUANG, L. \& SHEN, W. (2015): Characteristics of the pores and controlling factors of a shale gas reservoir: A case study from Longmaxi Formation of the Upper Yangtze region, China.- Earth Science Frontiers, 22/1, 374-385. doi: 10.13745/j. esf.2015.01.032

HILL, D.G. \& NELSON, C.R. (2000): Reservoir properties of the Upper Cretaceous Lewis shale - a new natural gas play in the San Juan Basin.-AAPG Bulletin, 84/8, 1240

JU, Y.W., BU, H.L. \& WANG, G.C. (2014): Main characteristics of shale gas reservoir and its effect on the reservoir reconstruction.- Advances in Earth Science, 29/4, 492-506. doi: 10.11867/j.issn.1001-8166.2014.04.0492

JARVIE, D.M., HILL, R.J., RUBLE, T.E. \& POLLASTRO, R.M. (2007): Unconventional shale-gas systems: the Mississippian Barnett shale of north-central Texas as one model for thermogenic shale-gas assessment.- Aapg Bulletin, 91/4, 475-499. doi: $10.1306 / 12190606068$

JIN, Z.J., HU, Z.Q., GAO, B. \& ZHAO, J.H. (2016): Controlling factors on the enrichment and high productivity of shale gas in the Wufeng and Longmaxi Formations, southeastern Sichuan Basin.- Earth Science Frontiers, 23/1, 001-010. doi:10.13745 j.esf.2016.01.001

KONG, L.M., WAN, M.X., YAN, Y. X., ZOU, C.Y., LIU, W.P., TIAN, C., YI, L. \& ZHANG, J. (2015): Reservoir diagenesis research of Silurian Niutitang Formation in Sichuan Basin.- Natural Gas Geoscience, 26/8, 1547-1555.

LI, R. X., ZHU, R.J., LIU, H.Q., ZHANG, Y.N. \& ZHU, D.M. (2013): Characteristics of Palaeozoic source rocks in Dabashan foreland tectonic belt-- Annual Meeting of the Chinese Society of Minerals, Petrology and Geochemistry, 92-93.

LI, T. (2010): The study of neoproterozoic tectonic-magmatic events in the northern margin of the Yangtze continent.- Thesis, master. Chang'an University, 1-69 p. (in Chinese with English abstract).

LI, Y.X., NIE, H.K. \& LONG, P.Y. (2009): Development characteristics of shale rich organic shale and strategic selection of shale gas in China.- Natural Gas Industry, 29/12, 115-118. doi: 10.3787/j.issn.1000-0976.2009.12.034

LU, X.C., LI, F.H. \& WATSON, A.T. (1995): Adsorption measurements in Devonian Shales.- Fuel, 74/4, 599-603.

LIU, Z.J. (2012): Gas evaluation of Lower Palaeozoic shale in southeastern Chongqing.Thesis, master. China University of Geosciences, 1-104 p. (in Chinese with English abstract).

LOUCKS, R.G. \& RUPPEL, STEPHEN, C. (2007): Mississippian Barnett shale: lithofacies and depositional setting of a deep-water shale-gas succession in the Fort Worth Basin, Texas.- Aapg Bulletin, 91/4, 579-601. doi: 10.1306/11020606059

MAO, Q., ZOU, G.F., ZHANG, H.M., JIN, H. \& HUANG, H.B. (2006): Discussion on geodynamic evolution and oil / gas prospect of the Sichuan Basin.- Natural Gas Industry, 26/11, 7-10. doi: 10.3321/j.issn:1000-0976.2006.11.0030
MU, C.L., ZHOU, K.K., LIANG, W. \& GE, X.Y. (2011): Early Palaeozoic sedimentary environment of hydrocarbon source rocks in the middle Upper Yangtze region and petroleum and gas exploration.- Acta Geologica Sinica, 85/4, 526-532.

PU, B.L., JIANG, Y.L., WANG, Y., BAO, S.J. \& LIU, X.J. (2010): Reservoir-forming conditions and favorable exploration zones of shale gas in Lower Silurian Longmaxi Formation of Sichuan Basin.- Acta Petrolei Sinica, 31/2, 225-230.

RACH, N.M. (2004): Drilling expands in Texas' largest gas field.- Oil \& Gas Journal, 102/3, 45-50. doi: 10.1016/j.ydbio.2010.05.240

REED, R.M, LOUCKS, R. G. \& JARVIE, D.M. (2007): Nanopores in the Mississippian Barnett shale: Distribution morphology, and possible genesis.- Gas Shales of North America, 39/6, 358

SHEN, J.A., LI, X.P., AN, S.T., JIN, H. \& HU, P.Q. (2017): Reservoir space and mineral composition of the shale from Silurian Longmaxi Formation in Sichuan Basin.- Geology and Resources, 26/6, 590-595. doi: 10.3969/j.issn.1671-1947. 2017.06.010

SCHETTLER, P.D. \& PARMOLY, C.R. (1990): The measurement of gas desorption isotherms for Devonian shale.-GRI Devonian Gas Shale Technology Review, 7/1, 4-9.

SHAO, X.H., PANG, X.Q., HU, T., XU, T.W., XU, Y.A., TANG, L., LI, H. \& LI, L.L. (2019): Microscopic characteristics of pores in $\mathrm{Es}^{3}$ shales and its significance for hydrocarbon retention in Dongpu Sag, Bohai Bay Basin.- Oil \& Gas Geology, 40/01, 67-77. doi: 10.11743/ogg20190107

SUN, J. \& L, B. (2016): Structural deformation and its influences on gas storage in Fuling shale gas play, the Sichuan Basin.- Oil \& Gas Geology, 37/06, 809-818. doi: 10.11743 ogg20160602

ULMISHE, G.F. \& KLEMMME, H.D. (1990): Depositional controls, distribution, and effectiveness of world's petroleum source rocks.- US Geological Survey Bulletin, 1931, 59.

VELIĆ, J., MALVIĆ, T., CVETKOVIĆ, M. \& VRBANAC, B. (2012): Reservoir Geology, Hydrocarbon Reserves and Production in the Croatian part of the Pannonian Basin System.- Geologia Croatica, 65/1, 91-101. doi: https://doi.org/10.4154/ GC.2012.07

VELDE, B. (1996): Compaction trends of clay-rich deep sea sediments.- Marine Geology, 133/3-4, 193-201. doi: 10.1016/0025-3227(96)00020-5

WANG, B. (2010): Genetic characteristics of organic fluids in the Dabashan foreland structure.- Thesis, master. Chang'an University, 1-83 p. (in Chinese with English abstract).

WANG, H., JIANG, C.F., ZHANG, L. \& GAO, C. (2017): Mineralogical characteristics of the shale from Shanxi Formation in southeastern Ordos Basin.- Petrochemical Industry Technology, 24/6, 129-130.

WANG, J.J. (2016): A Comparative study on shale gas geological character of Longmaxi and Niutitang Formations in South China.- Thesis, master. China University of Geosciences (Beijing), 1-68 p. (in Chinese with English abstract).

WU, C.J., ZHANG, M.F., MA, W.Y., LIU, Y., XIONG, D.M., SUN, L. \& TUO, J.C. (2014): Organic matter characteristic and sedimentary environment of the Lower Cambrian Niutitang shale in southeastern Chongqing.- Natural Gas Geoscience, 25/8, 1267-1274. doi: 10.11764/j.issn.1672-1926.2014.08.1267

WU, X.B., CHEN, J.X., HAO, Y.J. \& NA, Z.Q. (2013) Discovery and geological significance of the Silurian Xintan Formation seismite along the north margin of the Yangtze Plate.- Northwestern Geology, 46/2, 81-86. doi: 10.3969/j. issn.1009-6248.2013.02.010

WANG, L.B., JIU, K., ZENG, W.C., FU, J.L. \& ZHAO, S. (2012): Characteristics of Lower Cambrian marine black shale and evaluation of shale gas prospective area in Qianbei area, Upper Yangtze region.-Acta Petrologica Sinica, 29/9, 3263-3278.

WARLICK, D. (2006): Gas shale and CBM development in North America.- Oil and Gas Financial Journal, 3/11, 1-5.

WANG, S.J., WANG, L.S., HUANG, J.L., LI, X.J. \& LI, D.H. (2009): Accumulation conditions of shale gas reservoirs in Silurian of the Upper Yangtze region.- Natural Gas Industry, 29/5, 45-50.

WANG, S.F., DONG, D.Z., WANG, Y.M., LI, X.J., JIN, L. \& GUAN, Q.Z. (2015): A comparative study of the geological characteristics of marine shale gas between China and the United States.- Natural Gas Geoscience, 26/9, 1666-1678. doi: 10.11764/j.issn. 1672-1926.2015.09.1666

WEI, G.Q., YANG, W., LIU, M.C., XIE, W.R., JIN, H., WU, S.J., SU, N., SHEN, J.H. \& HAO, C.G. (2019): Distribution rules, main controlling factors and exploration directions of giant gas fields in the Sichuan Basin.- Natural Gas Industry, 39/6, $1-12$.

YU, B.S. (2013): Classification and characterization of the pores in shale gas reservoirs.Earth Science Frontiers, 20/4, 211-220.

ZHOU, Z.B., WANG, D.Q., WANG, X.C., ZHANG, L.H. \& ZHAO, Z.F. (1999): Analysis and development of potential natural gas market in Sichuan Basin.- Natural Gas Industry, (03), 117-118.

ZHANG, J.C., NIE, H.K., XU, B., JIANG, S.L., ZHANG, P.X. \& WANG, Z.Y. (2008): Geological condition of shale gas accumulation in Sichuan Basin.- Natural Gas Industry, 28/2, 151-156. doi: 10.3787/j.issn.1000-0976.2008.02.045 